\title{
EFFECT OF AQUEOUS EXTRACTS OF ULVA COMPOST ON GERMINATION AND SEEDLING GROWTH OF TEST PLANT Raphanus sativus L VAR. HYBRID 11
}

\author{
${ }^{1}$ Sunita Gaikwad* and ${ }^{2}$ Ashok Tuwar \\ $1^{*}$ B.J. Patel College Taloda, Tal. Taloda, Dist. Nandurbar. \\ Arts, Commerce \& Science College, Sonai, Tal. Newasa, Dist. Ahmednagar \\ *Corresponding Author: -sunitagulabraogaikwad@gmail.com
}

\begin{abstract}
:
Extensive use of synthetic chemical fertilizers and biocides. These disturbed the natural balance of soil nutrients that caused severe problem like reduction in soil fertility, soil erosion, desertification and ultimately the destruction of soil flora and fauna. The indiscriminate use of synthetic agrochemicals resulted in poisoning the soil, killing soil micro-organisms, stunning plants and causing harmful diseases in plants and animals and human beings. Therefore, biofertilizers are to be used for better agricultural output and to maintain the quality of soil. The term 'biofertilizers' can be increase nutrient availability to the plants. Today, various eco-friendly organic fertilizers have been developed. It is an established fact that algae, especially seaweeds can be used as good renewable source of biofertilizers.

To find out the effect of different concentration of fresh aqueous extract of an alga Ulva compost extract of different concentration viz. $2.5 \%, 5 \%, 7.5 \%$, increased the root growth, shoot growth, and total seedling growth of the test plant Raphanus sativus L. var. 'Hybrid 11' seedling growth promotion was co - related with extract concentration.
\end{abstract}

Key word: Raphanus sativus L., Ulva., biofertilizers, ecofriendly, microorganisms.

\section{INTRODUCTION:}

In India, after independence modern techniques have been used for the progress of the nation and much emphasis has been given on agricultural and industrial production. Today we are one of the wellindustrialized nations in the world. To fulfill the demands of increasing population, agriculture became highly mechanized and intensive but completely dependent on synthetic biocides and fertilizers. After few years of practicing these methods of agriculture, we became aware about the decreasing soil productivity and profitability, destruction of natural ecosystems that lead to the problems like pollution, eco-degradation and ultimately human health hazards. It is the time to think about sustainability in development, pollution control and conservation of natural resources like air, water, soil etc. The main cause of the soil deterioration is the extensive use of synthetic chemical fertilizers and biocides. These disturbed the natural balance of soil nutrients that caused severe problem like reduction in soil fertility, soil erosion, desertification and ultimately the destruction of soil flora and fauna. The indiscriminate use of synthetic agrochemicals resulted in poisoning the soil, killing soil microorganisms, stunning plants and causing harmful diseases in plants and animals and human beings. Exactly opposite to this is the sustainable agriculture system. It does not mean only organic or low output farming but also to produce good quality of food, conservation of resources and use of renewable resources available from the farm itself. To understand this phenomenon, one must know the importance of soil. Soil is not the instrument of crop production to use year after year carelessly. Healthy soil, a complex living medium is the base of the agriculture. Soil flora 
including bacteria, fungi and algae, fauna, macro and microelements are its major constituents.

Algae are a collective term applied to a group of primitive, autotrophic and thalloid plants that algae use sunlight to make their own food, through a process called photosynthesis. They are ubiquitous, ranging from microscopic unicellular $(1 \mu \mathrm{m})$ to multicellular gigantic kelps ( hundreds of meters in length) that inhabit the oceans, fresh water bodies, soils, rocks, trees, etc and are responsible for most of the global production of organic matter. They play a fundamental role in the aquatic ecosystems.

Medcalf et al (1975) worked on seasonal variation in yield of water-soluble polysaccharides, ash, sulfate, uronic acid, and neutral sugar contents of Ulva lactuca. Maximum production of polysaccharide yield was highest during June and July. Brantsevich (1975) treated cabbage and tomato crop plants with blue green algae as organic fertilizer and recorded an increase in ammonium and nitrate nitrogen contents of soil, leaf nitrate reductase activity and crop yield. Yamaguchi (1976) listed symbiotic and non-symbiotic microorganisms capable of fixing nitrogen and occurring in paddy fields and their contribution to their nitrogen supply in soil. He recorded increase in rice yield by $15-25 \%$ by inoculating blue green algae (eg. Tolypothrix) in paddy fields $\mathrm{He}$ also suggested enhancement of microbial nitrogen fixation by liming. Crawford (1977) studied chemical, physical and biological changes associated with Chara succession in ponds. Analysis of Chara-dominated pond water revealed lower free $\mathrm{CO}_{2}$, bicarbonate alkalinity and total hardness. He also recorded high dissolved $\mathrm{O}_{2}$ and low phosphates. Griffiths
(1978) investigated specific blue green algal carotenoids in sediments of Esthwaite lake water. Maximum carotenoids viz. Oscillaxanthin and Myxoxanthophyll were found in the sediments correlated to maximal growth of Oscillatoria species in the lake water.Dave and Parekh (1978) detected amino acids in protein hydrolyzates of Ulva fasciata, Ulva lactuca, Ulva profunda, Ulva rigida, and Ulva stenophylla from different parts of Saurashtra coast of India. They used two-dimensional paper Chromatography technique for separating and estimating amino acids. They recorded maximum aspartic acid in all samples. Tryptophan and Cysteic acids were detected for the first time in marine algae.

\section{MATERIALS AND METHOD:}

Ulva lactuca 1. was collected from konkan harnai, kolthare and alibag growing in shallow tide pools and rock pools, attached to stones or rocks and even on open rock surfaces. the collected material was washed with tap water. make a ulva compost with compost extract of ulva compost 1 . of different concentration viz. $2.5 \%, 5 \%, 7.5 \%$, were prepared in distilled water.

Seeds of test plants Raphanus sativus L. var. 'Hybrid 11' procured from local market were surface sterilized with $0.1 \%$ mercuric chloride and washed thoroughly. 30 seeds were placed in three Petri dishes. Germinating paper was used $10 \mathrm{ml}$ Ulva compost extract was added in every Petri plate. Seeds were allowed to geminate in the laboratory conditions. On $5^{\text {th }}$ day measurements of seedling growth were taken. Percentage inhibition or stimulation over control and ANOVA variance was calculated.

\% Inhibition or stimulation: (C-T /C) X100

(Where C: control, T: treatment).

REASULT AND DISCUSION: 
(C)Effect on 'Hybrid 11' variety: Extract of Ulvacompost promoted $\mathrm{Rg}, \mathrm{Sg}$, and TSg of the third variety 'Hybrid 11'of the test crop plant Raphanus sativus L. at $0.05 \% \mathrm{P}$ - value. Root growth $(\mathrm{Rg})$ was promoted minimally (37.4\%) at $2.5 \%$ concentration and promoted maximally at $7.5 \%$ concentration $(47.48 \%)$ over control. Shoot growth (Sg) was significantly promoted minimally $(11.42 \%)$ at $2.5 \%$ concentration and promoted maximally at $7.5 \%$ concentration (55\%) over control. Total seedling growth (TSg) was promoted minimally (25.64\%) at $2.5 \%$ and promoted maximally at $7.5 \%$ concentration (50.85\%) over control. Seed germination was promoted minimally by $20.83 \%$ at $5 \%, 7.5 \%$ and maximally by $25 \%$ at $2.5 \%$ a concentrations respectively over control.

\section{REFERENCES:}

Medcalf D. G., Lionel T., Brannon J.H. and Scott, J.R. (1975) Seasonal variation in the
Mucilaginous polysaccharides from Ulva lactuca, Botanica Marina, Vol 18: Pp. 6770.

Brantsevich L.G., Monastyretskaya E. V. and Svyatnenko L. P. (1975) Nitrate reductase activity in cabbage and tomato plants treated with blue green algae as organic fertilizer. Fiziolgiya-i-Biokhimiya Kulturnykh-Rastenii, Vol 7 (5): Pp.506- 512.

Crawford S. A. (1977) Chemical, physical and biological changes associated with Chara succession from ponds. Hydrobiologia, Vol 55 (3): Pp.209-215.

Yamaguchi M. (1976) Nitrogen fixation by microorganisms in paddy soils relation to their fertility.pub. By ASPAC Food and fertilizer Technology center, Taiwan, Pp. 60 - 75. http://www.polan.intranet@mpkv.

Griffiths M. (1978) Specific blue-green algal carotenoids in sediments of Esthwaite water. The Limnology Oceanogr Vol 23 (4): Pp. $777-784$.

Dave M.J. and Parekh R.G. (1978) Amino acids of the green algae Ulva. Botanica Marina, Vol 21: Pp. 323-326. 
Table-1: Effect of Ulva compost extract of higher concentration on germination and seedling growth of crop plant Raphanus sativus L. var. Hybrid 11

\begin{tabular}{|c|c|c|c|c|c|c|c|}
\hline \multirow[b]{2}{*}{ Test variety } & \multirow[b]{2}{*}{$\begin{array}{l}\text { Growth } \\
\text { Parameters }\end{array}$} & \multirow[b]{2}{*}{ Control } & \multicolumn{4}{|c|}{ Extract Concentration } & \multirow[b]{2}{*}{$\begin{array}{l}P \text { - Value at } \\
0.05 \%\end{array}$} \\
\hline & & & $2.50 \%$ & $5 \%$ & $7.50 \%$ & $\begin{array}{l}\text { CD at } \\
0.05 \%\end{array}$ & \\
\hline \multirow{4}{*}{ 'Hybrid 11' } & $\operatorname{Rg}(\mathrm{cm})$ & $5.16 \mathrm{a} \pm 0.50$ & $\begin{array}{c}7.09 \mathrm{~b} \pm 0.74 \\
(37.4)\end{array}$ & $\begin{array}{c}7.51 \mathrm{bc} \pm 1.04 \\
(45.54)\end{array}$ & $\begin{array}{c}7.61 \mathrm{bd} \pm 0.56 \\
(47.48)\end{array}$ & 0.41 & 0.007 \\
\hline & $\mathrm{Sg}(\mathrm{cm})$ & $4.20 \mathrm{a} \pm 0.41$ & $\begin{array}{c}4.68 \mathrm{ab} \pm 0.51 \\
(11.42)\end{array}$ & $\begin{array}{c}5.95 \mathrm{c} \pm 1.02 \\
(41.67)\end{array}$ & $\begin{array}{c}6.51 \mathrm{~d} \pm 0.82 \\
(55.00)\end{array}$ & 0.37 & 0.0009 \\
\hline & TSg (cm) & $9.36 a \pm 0.86$ & $\begin{array}{c}11.76 \mathrm{~b} \pm 1.19 \\
(25.64)\end{array}$ & $\begin{array}{c}13.46 c \pm 0.90 \\
(43.80)\end{array}$ & $\begin{array}{c}14.12 \mathrm{~cd} \pm 0.64 \\
(50.85)\end{array}$ & 0.71 & 0.002 \\
\hline & Ger \% & 80 & $\begin{array}{c}100 \\
(25.00)\end{array}$ & $\begin{array}{c}96.67 \\
(20.83)\end{array}$ & $\begin{array}{c}96.67 \\
(20.83)\end{array}$ & & \\
\hline
\end{tabular}

Data presented are means of three replicates; values within the same row with different letters are significantly different at $0.05 \%$ P-level by Single factor ANOVA test followed by CD \& Tukey's test.

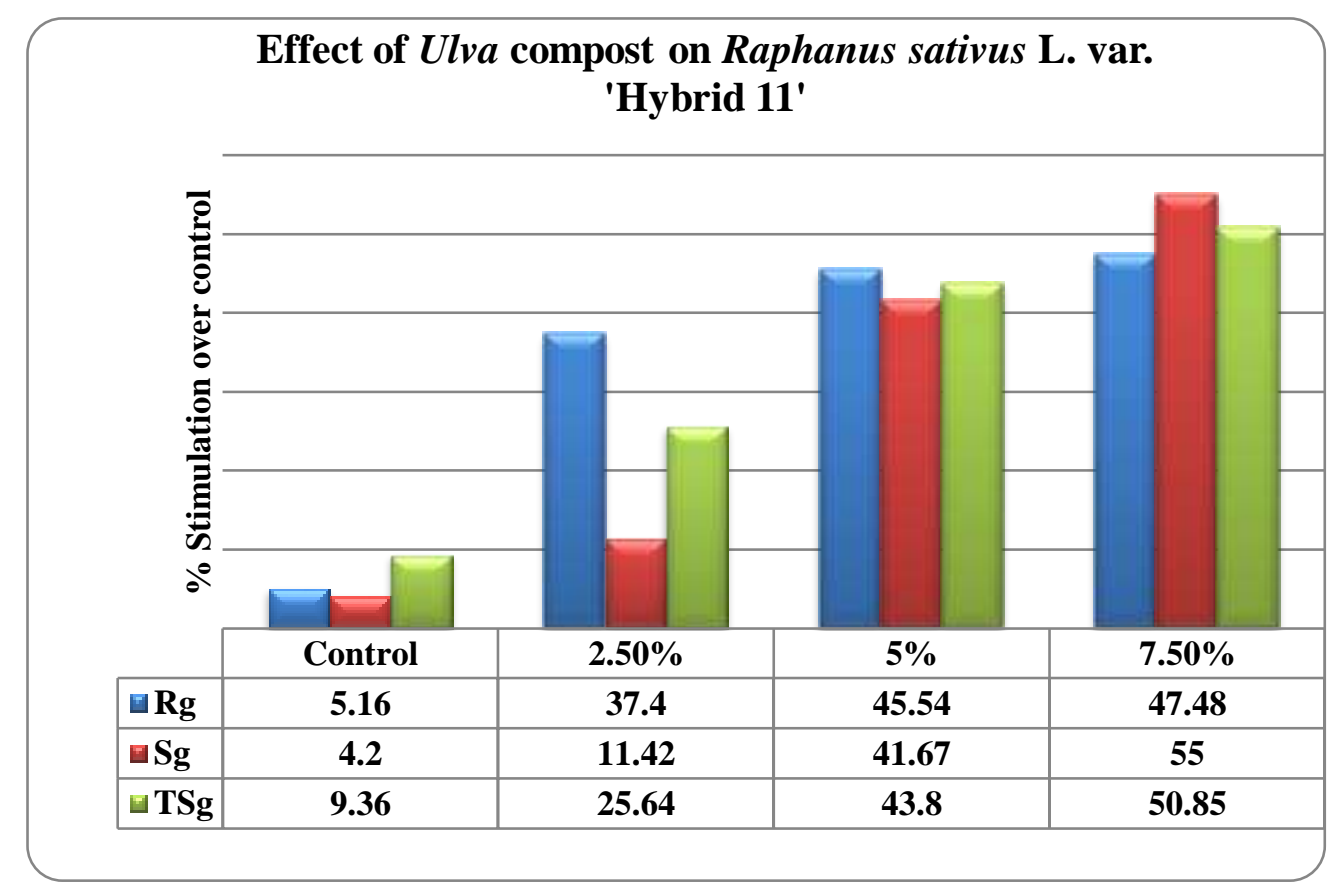

